New appr oach to ol i got ri azol es usi ng a cobal $t$ compl ex of propargyl azi des as a synt het i c component

\begin{tabular}{|l|l|}
\hline 著者 & $\begin{array}{l}\text { Tsukada Yui chi, Yamada Kohei , Kuni shi ma } \\
\text { Munet aka }\end{array}$ \\
\hline $\begin{array}{l}\text { j our nal or } \\
\text { publ i cat i on t i t l e }\end{array}$ & Tet r ahedr on Let t er s \\
\hline vol une & 52 \\
\hline number & 26 \\
\hline page r ange & 3358 3360 \\
\hline year & 2011- 01-01 \\
\hline URL & ht t p: //hdl . handl e. net /2297/27787 \\
\hline
\end{tabular}




\section{Graphical Abstract}

To create your abstract, type over the instructions in the template box below.

Fonts or abstract dimensions should not be changed or altered.

New approach to oligotriazoles using a cobalt

complex of propargyl azides as a synthetic

\section{component}

Yuichi Tsukada, Kohei Yamada, and Munetaka Kunishima*
Leave this area blank for abstract info.

$$
\text { PhCOHN } \stackrel{P}{\longrightarrow} \text { PhCOHN }
$$


Tetrahedron Letters

journal homepage: www.elsevier.com

\title{
New approach to oligotriazoles using a cobalt complex of propargyl azides as a synthetic component
}

\author{
Yuichi Tsukada, Kohei Yamada, and Munetaka Kunishima* \\ ${ }^{a}$ Faculty of Pharmaceutical Sciences, Institute of Medical, Pharmaceutical, and Health Sciences, Kanazawa University, Kakuma-machi, Kanazawa 920-1192, \\ Japan
}

\section{ARTICLE INFO}

\section{ABSTRACT}

\section{Article history:}

Received

Received in revised form

Accepted

Available online

\section{Keywords:}

Oligotriazole;

Peptidomimetic;

Click chemistry;

Cobalt alkyne complex;

Nicholas reaction;

\begin{abstract}
We have developed an efficient method for preparation of triazolamers using a dicobalt hexacarbonyl complex of propargyl azides (CPA) as a synthetic component. Several types of CPAs possessing the side chains (R) found in the natural amino acids were prepared by Nicholas reaction as well as by a reaction of propargyl azides with dicobalt octacarbonyl. Triazolamers with both amino and carboxyl termini were readily synthesized by repetitive reaction sequence involving a copper-catalyzed 1,3-dipolar cycloaddition followed by an oxidative deprotection.
\end{abstract}

2009 Elsevier Ltd. All rights reserved.
According to the recent developments of $\mathrm{Cu}(\mathrm{I})$-catalyzed azide-alkyne 1,3-dipolar cycloaddition (CuAAC) as the most useful ligation process in click chemistry, ${ }^{1,2}$ a variety of compounds with 1,4-disubstituted 1,2,3-triazole backbone have been synthesized. ${ }^{3}$ The 1,2,3-triazole linkage has been revealed to be a promising amide bond surrogate, particularly with respect to its structure and hydrogen-bonding ability, while it shows a higher chemical and biological stability in comparison with the amide bonds. ${ }^{4}$ Thus, it is now of great interest to elucidate the effects of replacement of an amide bond with a 1,2,3-triazole ring on the secondary structure as well as on the bioactivities in a wide range of amides. Recently, Angelo and Arora introduced a new class of oligotriazole as a peptidomimetic, named tirazolamer, in which the triazole rings and the $\mathrm{sp}^{3}$-hybridized carbons possessing amino acid side chains are alternately connected. They indicated that optically active trimeric and tetrameric triazolamers adopt zigzag conformations and show a potential inhibitory activity of HIV-1 protease. ${ }^{5}$

Their synthetic method for preparation of triazolamer employs $\mathrm{N}$-Boc propargylamines derived from amino acids as a synthetic component and involves a three-step iterative reaction sequence; diazotransfer to amines, $\mathrm{CuAAC}$ reaction of the resulting azides with $N$-Boc propargylamines, followed by deprotection of the amines. $^{5 a}$ On the other hand, Hughes and co-workers described a more convenient synthesis of triazolamers employing propargyl azide possessing a trialkylsilyl group at the acetylenic terminal. ${ }^{6}$ Since the silyl group prevents the propargyl azides from selfpolymerization by $\mathrm{CuAAC}$ reaction, extension of a triazolic chain can be attained by a two-step iterative reaction sequence involving CuAAC reaction and desilylation. In this letter, we wish to report a new approach to the synthesis of triazolamers utilizing a dicobalt hexacarbonyl complex of propargyl azides (CPA) as a synthetic component.<smiles>[R2]C(NC(=O)C([R])([R])N)C(C)(C)C(=O)O</smiles><smiles>[R]C(N)C(C)(CC)c1cn(C([R2])(C)C(=O)O)nn1</smiles>

Alkynes are known to readily react with dicobalt octacarbonyl by simple mixing to the formation of alkyne-dicobalt hexacarbonyl complex, which can undergo oxidative degradation to liberate the alkynes. ${ }^{7}$ Thus, if the alkyne-cobalt complexes are inert to CuAAC, chain extension of triazolamers can be accomplished by only a repetition of $\mathrm{CuAAC}$ and oxidative deprotection of alkynes. Variety of CPAs can be readily prepared from not only propargyl azide with dicobalt octacarbonyl, but also propargyl alcohols or alk-3-en-1-yne compounds by Nicholas reaction via the alkyne-cobalt complexes. ${ }^{7,8}$

We employed several types of CPA possessing a substituent (R) corresponding to the side chain of the natural amino acids. As 
we had expected, CPAs (2a-f) were readily prepared from the corresponding propargyl alcohols $(\mathbf{1 a}-\mathbf{f})$ by Nicholas reaction using $\mathrm{TMSN}_{3}$ and $\mathrm{BF}_{3}-\mathrm{Et}_{2} \mathrm{O}$ (Table 1). ${ }^{9}$ Since $\mathbf{2 g}(\mathrm{R}=$ $\mathrm{CH}_{2} \mathrm{CH}_{2} \mathrm{SMe}$ ) possessing the side chain of methionine was found to be difficult to synthesize by the same method presumably due to the high nucleophilicity of sulfide group, it was prepared in a stepwise fashion from $\mathbf{1 g}$ in $61 \%$; mesylation of the hydroxyl group 1g, nuculeophilic substitution with sodium azide, followed by complexation with $\mathrm{Co}_{2}(\mathrm{CO})_{8}(\mathrm{Eq} 1)$.

Table 1. Preparation of CPA 2 by Nicholas Reaction

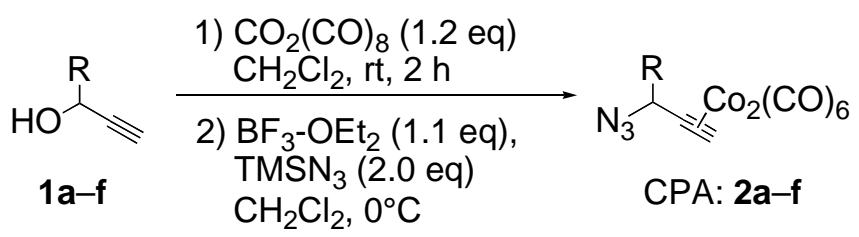

\begin{tabular}{llll}
\hline CPA (2) & $\mathrm{R}$ & Reaction time $^{\mathrm{a}}$ & ${\text { Yield } \%^{\mathrm{b}}}^{\mathrm{a}}$ \\
\hline $\mathbf{2 a}$ & $\mathrm{H}$ & $10 \mathrm{~h}$ & 81 \\
$\mathbf{2 b}$ & $\mathrm{Me}$ & $6 \mathrm{~h}$ & 78 \\
$\mathbf{2 c}$ & $i-\mathrm{Bu}$ & $3 \mathrm{~h}$ & 88 \\
$\mathbf{2 d}$ & $\mathrm{Bn}$ & $16 \mathrm{~h}$ & 79 \\
$\mathbf{2 e}$ & $\mathrm{CH}_{2} \mathrm{OAc}$ & $8 \mathrm{~h}$ & 71 \\
$\mathbf{2 f}$ & $\mathrm{CH}_{2} \mathrm{CH}_{2} \mathrm{COOMe}$ & $5 \mathrm{~h}$ & 86 \\
\hline
\end{tabular}

${ }^{\mathrm{a}}$ The reaction time of the second step.

${ }^{b}$ Yields from 1.

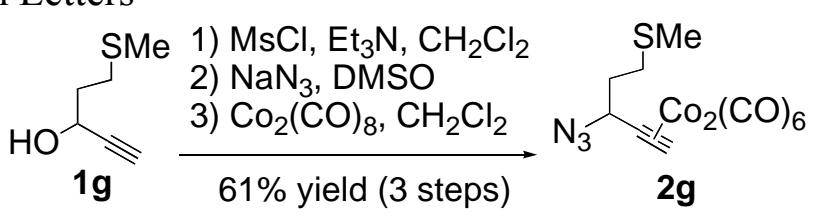

Eq 1

We designed triazolamers possessing both amino and carboxyl groups on their termini to mimic the structure of peptide chains (Scheme 1). The CuAAC reaction between $2 \mathbf{a}$ and $N$ benzoylpropargylamine $\mathbf{3}$ was attempted under several conditions according to literatures, ${ }^{2 \mathrm{~b}, 10}$ and the best yield of $\mathbf{4 a}$ was obtained by using $\mathrm{CuSO}_{4}$ and sodium L-ascorbate in a heterogeneous mixed solvent of dichloromethane and water $(1: 1) .^{10 a}$ The crude reaction mixture obtained by $\mathrm{CuAAC}$ was directly treated with ceric ammonium nitrate (CAN) for deprotection of the alkyne followed by purification by column chromatography to give the corresponding monotriazole $4 a$ in $76 \%$ yield. ${ }^{11}$ The second reaction cycle was carried out on the resulting 4a using various types of CPA $2 \mathbf{a}-\mathbf{g}$ under the same conditions, and bis(triazoles) 5 with various substituents were obtained in reasonable yields. The final elongation of 5 with methyl azidoacetate 6 gave tris(triazoles) 7 in good yields.

Epimerization at the asymmetric $\alpha$-carbon of the carbonyl groups of peptide bonds has been a major challenge in peptide synthesis, as seen in its history. Thus, it is essential to employ synthetic methods free form racemization at the $\alpha$-carbon in preparation of peptides. Since the same thing holds true for preparation of chiral triazolamers, we examined the possibility that our synthetic method is accompanied by epimerization at the asymmetric $\alpha$-carbon between two triazoles and/or at the propargyl carbon of CPA. As shown in Scheme 2, by using (S)2d, ${ }^{12,13}$ whose enantiomeric purity was $92 \%$ ee, we synthesized triazole 4d and bis(triazole) 8 in 79\% and 75\% yield, respectively. Both of them exhibited exactly the same enantiomeric purity as 2d ( $92 \%$ ee), indicating that no epimerization took place during a series of reactions for preparing triazolamers in the present procedure.

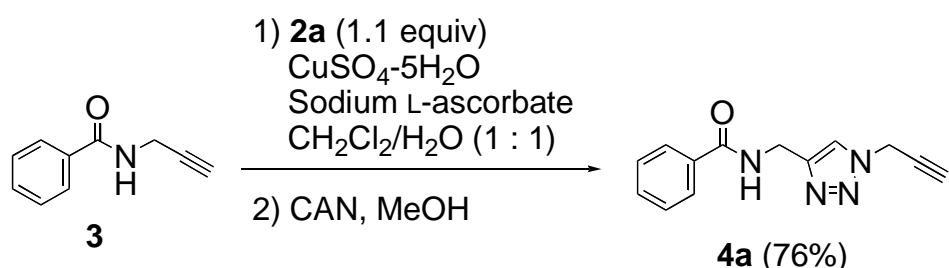

$4 a(76 \%)$
1) $2 \mathbf{a}-\mathbf{g}$ (1.1 equiv) $\mathrm{CuSO}_{4}-5 \mathrm{H}_{2} \mathrm{O}$ Sodium L-ascorbate $\mathrm{CH}_{2} \mathrm{Cl}_{2} / \mathrm{H}_{2} \mathrm{O}(1: 1)$

2) $\mathrm{CAN}, \mathrm{MeOH}$ 5a: $\mathrm{R}=\mathrm{H}(67 \%)$
5b: $\mathrm{R}=\mathrm{Me}(68 \%)$
5c: $\mathrm{R}=i-\mathrm{Bu}(76 \%)$
5d: $\mathrm{R}=\mathrm{Bn}(75 \%)$
5e: $\mathrm{R}=\mathrm{CH}_{2} \mathrm{OAc}(66 \%)$
5f: $\mathrm{R}=\mathrm{CH}_{2} \mathrm{CH}_{2} \mathrm{COOMe}(70 \%)$
5g: $\mathrm{R}=\mathrm{CH}_{2} \mathrm{CH}_{2} \mathrm{SMe}(72 \%)$

Scheme 1 


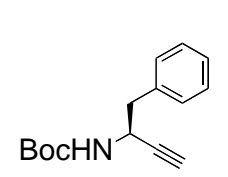

1) TFA, $\mathrm{CH}_{2} \mathrm{Cl}_{2}$

2) $\mathrm{Co}_{2}(\mathrm{CO})_{8}, \mathrm{CH}_{2} \mathrm{Cl}_{2}$

3) $\mathrm{TfN}_{3}, \mathrm{CuSO}_{4}, \mathrm{~K}_{2} \mathrm{CO}_{3}$ $\mathrm{CH}_{2} \mathrm{Cl}_{2} / \mathrm{MeOH} / \mathrm{H}_{2} \mathrm{O}$

$92 \%$ ee

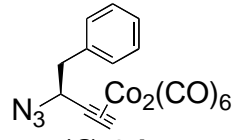

(S)-2d

$89 \%$ yield (3 steps) $92 \%$ ee
1) (S)-2d

$\mathrm{CuSO}_{4}-5 \mathrm{H}_{2} \mathrm{O}$<smiles>C#CCNC(=O)c1ccccc1</smiles>

3 $\mathrm{CH}_{2} \mathrm{Cl}_{2} / \mathrm{H}_{2} \mathrm{O}(1: 1)$

2) $\mathrm{CAN}, \mathrm{MeOH}$

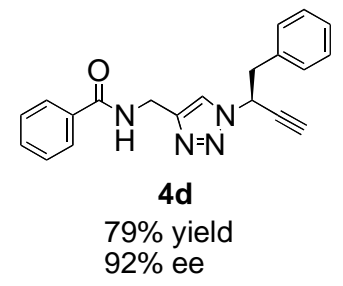

1) $2 a$

$\mathrm{CuSO}_{4}-5 \mathrm{H}_{2} \mathrm{O}$

Sodium L-ascorbate

$\mathrm{CH}_{2} \mathrm{Cl}_{2} / \mathrm{H}_{2} \mathrm{O}(1: 1)$

2) $\mathrm{CAN}, \mathrm{MeOH}$ Sodium L-ascorbate

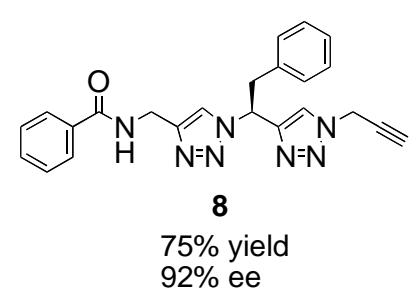

$92 \%$ yield

\section{Scheme 2}

In conclusion, we have demonstrated a new strategy for the synthesis of triazolamer using CPAs 2 as a monomeric synthetic component. The cobalt complex has two different roles in our method; one is the protection of alkynes, and the other is the essential activating group for Nicholas reaction to prepare CPAs, in part. The chain extension of triazolamer is conveniently attained without racemization by iteration of reaction sequence of CuAAC and oxidative deprotection. Further applications of our method for preparation of various oligotriazoles are currently under investigation.

\section{References and notes}

1. (a) Kolb, H. C.; Finn, M. G.; Sharpless, K. B. Angew. Chem. Int. Ed. 2001, 40, 2004-2021; (b) Kolb, H. C.; Sharpless, K. B. Drug Discovery Today 2003, 8, 1128-1137.

2. (a) Rostovtsev, V. V.; Green, L. G.; Fokin, V. V.; Sharpless, K. B. Angew. Chem. Int. Ed. 2002, 41, 2596-2599; (b) Tornøe, C. W.; Christensen, C.; Meldal, M. J. Org. Chem. 2002, 67, 3057-3064; (c) Meldal, M. ; Tornøe, C. W. Chem. Rev. 2008, 108, 2952-3015.

3. Chow, H.-F.; Lau, K.-N.; Ke, Z.; Liang, Y.; Lo, C.-M. Chem. Commun. 2010, 46, 3437-3453.

4. (a) Bourne, Y.; Kolb, H. C.; Radic', Z.; Sharpless, K. B.; Taylor, P.; Marchot, P. Proc. Natl. Acad. Sci. U.S.A. 2004, 101, 1449-
1454; (b) Horne, W. S.; Yadav, M. K.; Stout, C. D.; Ghadiri, M. R. J. Am. Chem. Soc. 2004, 126, 15366-15367; (c) Brik, A.; Alexandratos, J.; Lin, Y. C.; Elder, J. H.; Olson, A. J.; Wlodawer, A.; Goodsell, D. S.; Wong, C. H. ChemBioChem 2005, 6, 11671169; (d) Appendino, G.; Bacchiega, S.; Minassi, A.; Cascio, M. G.; De Petrocellis, L.; Di Marzo. V. Angew. Chem. Int. Ed. 2007, 46, 9312-9315.

5. (a) Angelo, N. G.; Arora, P. S. J. Am. Chem. Soc. 2005, 127, 17134-17135; (b) Angelo, N. G.; Arora, P. S. J. Org. Chem. 2007, 72, 7963-7963; (c) Jochim, A. L.; Miller, S. E.; Angelo, N. G.; Arora, P. S. Bioorg. Med. Chem. Lett. 2009, 19, 6023-6026.

6. Montagnat, O. D.; Lessene, G.; Hughes, A. B. Tetrahedron Lett. 2006, 47, 6971-6974.

7. Nicholas, K. M.; Pettit, R. Tetrahedron Lett. 1971, 12, 3475-3478.

8. Teobald, B. J. Tetrahedron 2002, 58, 4133-4170.

9. Gómez, A. M.; Uriel, C.; Valverde, S.; López, J. C. Org. Lett. 2006, 8, 3187-3190.

10. (a) Lee, B.-Y.; Park, S. R.; Jeon, H. B.; Kim, K. S. Tetrahedron Lett. 2006, 47, 5105-5109. (b) Wu, P.; Feldman, A. K.; Nugent, A. K.; Hawker, C. J.; Scheel, A.; Voit, B.; Pyun, J.; Fréchet, J. M. J.; Sharpless, K. B.; Folkin V. V. Angew. Chem. Int. Ed. 2004, 43, 3928-3932. (c) Li, Y.; Huffman, J. C.; Flood, A. H. Chem. Commun. 2007, 26, 2692-2694. (d) Lee, J. W.; Kim, B.-K.; Kim, J. H.; Shin, W. S.; Jin, S.-H. J. Org. Chem. 2006, 71, 4988-4991. (e) Li, Z.; Bittman, R. J. Org. Chem. 2007, 72, 8376-8382.

11. General procedure for chain extension by use of CPA. Preparation of $\mathbf{5 d}$ as a typical example. To a solution of $\mathbf{4 a}(120 \mathrm{mg}, 0.500$ $\mathrm{mmol})$ and $2 \mathbf{d}(251 \mathrm{mg}, 0.550 \mathrm{mmol})$ in $\mathrm{CH}_{2} \mathrm{Cl}_{2}(1.00 \mathrm{~mL})$ were added an aqueous solution of $\mathrm{CuSO}_{4} \cdot 5 \mathrm{H}_{2} \mathrm{O}(0.200 \mathrm{M}, 0.50 \mathrm{~mL})$ and an aqueous solution of sodium L-ascorbate $(1.3 \mathrm{M}, 0.50 \mathrm{~mL})$. The resulting solution was stirred for $1.5 \mathrm{~h}$ at room temperature, and was diluted with $\mathrm{CH}_{2} \mathrm{Cl}_{2}$ and $\mathrm{H}_{2} \mathrm{O}$. The organic layer was separated and washed with brine, dried over $\mathrm{Na}_{2} \mathrm{SO}_{4}$, and concentrated under vacuum. The crude mixture was dissolved in $\mathrm{MeOH}(5.0 \mathrm{~mL})$ followed by addition of CAN (1.51 g, 2.75 $\mathrm{mmol}$ ), and then stirred for $5 \mathrm{~min}$ at room temperature. The reaction mixture was extracted with $\mathrm{CH}_{2} \mathrm{Cl}_{2}$, and the combined organic layers were washed with water, brine, dried over $\mathrm{Na}_{2} \mathrm{SO}_{4}$, and concentrated under vacuum. The residue was purified by flash column chromatography (hexane/EtOAc, $2: 8)$ to give $5 d(155 \mathrm{mg}$, $75 \%$ yield) as a white solid. mp $168-170{ }^{\circ} \mathrm{C} .{ }^{1} \mathrm{H}$ NMR $(400 \mathrm{MHz}$, $\left.\mathrm{CDCl}_{3}\right) \delta$ 7.81-7.76 (m, 2H), $7.67(\mathrm{~s}, 1 \mathrm{H}), 7.56(\mathrm{~s}, 1 \mathrm{H}), 7.54-7.39$ $(\mathrm{m}, 3 \mathrm{H}), 7.25-7.19(\mathrm{~m}, 3 \mathrm{H}), 7.04-6.98(\mathrm{~m}, 2 \mathrm{H}), 6.85$ (br. s, $1 \mathrm{H})$, 5.66 (ddd, $J=2.3,5.5,7.1 \mathrm{~Hz}, 1 \mathrm{H}), 5.60(\mathrm{~s}, 2 \mathrm{H}), 4.72(\mathrm{~d}, J=5.5$ $\mathrm{Hz}, 2 \mathrm{H}), 3.38$ (dd, $J=5.5,13.7 \mathrm{~Hz}, 1 \mathrm{H}), 3.34$ (dd, $J=7.1,13.7 \mathrm{~Hz}$, $1 \mathrm{H}), 2.64(\mathrm{~d}, J=2.3 \mathrm{~Hz}, 1 \mathrm{H}) ;{ }^{13} \mathrm{C}$ NMR $\left(100 \mathrm{MHz}, \mathrm{CDCl}_{3}\right) \delta$ $167.3,144.9,141.0,134.0,133.9,131.7,129.5,128.6,128.5$, $127.7,127.0,122.6,122.3,77.8,77.2,54.1,45.4,42.8,35.4$; HRMS $\mathrm{m} / \mathrm{z}$ for $\mathrm{C}_{23} \mathrm{H}_{22} \mathrm{~N}_{7} \mathrm{O}(\mathrm{M}+\mathrm{H})^{+}$, calcd 412.1886, found 412.1876; IR $\left(\mathrm{CHCl}_{3}\right)$ 3297, 3001, 1658, 1521, $1053 \mathrm{~cm}^{-1}$.

12. Reginato, G.; Mordini, A.; Messina, F.; Degl'Innocenti, A.; Poli, G. Tetrahedron 1996, 52, 10985-10996.

13. Recently, an asymmetric Nicholas reaction has been reported (see: ref. 14). Unfortunately, however, an enantioselective preparation of CPAs by Nicholas reaction have not appeared yet, to the best of our knowledge.

14. Ljungdahl, N.; Pera, N. P.; Andersson, K. H. O.; Kann, N. Synlett 2008, 394-398. 